\title{
水圧マニピュレータを有する移動作業ロボットの開発
}

\section{Development of mobile working robot that has water hydraulic manipulator}

$\begin{array}{rlllll}\text { 学 } & \text { 芦澤 } & \text { 怜史 (名城大) } & & \text { 脇田 } & \text { 昌明 (名城大) } \\ \text { 学 } & \text { 渡辺 } & \text { 聖也 (名城大) } & \text { 学 } & \text { 黒宮 } & \text { 裕介 (名城大) } \\ & \text { 高柳 } & \text { 一樹 (名城大) } & \text { 正 } & \text { 大道 } & \text { 武生 (名城大) }\end{array}$

Satoshi ASHIZAWA, Meijo University, e0527070@ccmailg.meijo-u.ac.jp

Masaaki WAKITA, Meijo University

Toshiya WATANABE, Meijo University

Yusuke KUROMIYA, Meijo University

Kazuki TAKAYANAGI, Meijo University

Takeo OOMICHI, Meijo University

The mobile robot that has the water hydraulic manipulator for the dismantlement of the building as the base machine is developed. The paper shows the system design method and mock-up test of this robot.

Key Words: Manipulator, Dismantlement work, Mobile robot

\section{1. 緒言}

環境保全等の観点から，ビルのリニューアル再利用化は時 代の流れとなっていると同時に，このリニューアルのための 解体作業で生じる廃棄物のリサイクルは重要な課題となって いる。.また，少子高齢化による解体作業者の確保も無視でき ない状況になりつつある。このような中で, ビルの内装解体 は，リニューアルの中核を占めるものであるが，現状の解体 作業は人手作業が中心であり，問題解決に応えるには，限界 がある $[1]$.

したがって，この問題を解決するためには，新しいシステ 厶的発想が必要であると判断された。 天井解体工事において, ロボット化を成功させるためには，ロボットの特徵を生かせ る新しい解体手法が必要であること [2]に着目し，ウォータジ エットによる切断を用いた新しい解体システムを開発し，そ のロボット化の見通しを得た。本稿ではその基本となる移動 作業ロボットについて述べる.

\section{2. 解体手法の課題整理}

現状の天井ボード（図 1) 解体は，人がバール状の金具で強 引に引き剥がし解体を行っている. そのため, 解体後の天井 ボードは床面に散乱し，その回収には，解体の何倍もの時間 を要する。また，作業中に多量の粉塵を発生し作業環境の悪 化という久点を有する。そこで, 著者らは, ウォータジェッ ト天井ボード解体手法[3]を提案し工法開発を行ってきた．ウ オータジェットによる天井ボード解体手法では, 軽量鉄骨 (以 下軽鉄）を損傷することなく天井ボードを解体することが可 能である。また，解体速度に配慮すれば，軽鉄下を切断する ことが必要となる.

したがって，軽鉄下を高精度（土5mm 程度）で走査できる 図 2 に示すような解体作業口ボットを構想し開発を行った.

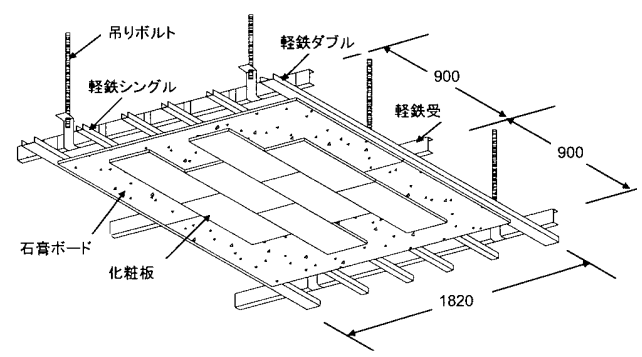

Fig. 1 Setting situation of LGS(Light Gauge Steel)

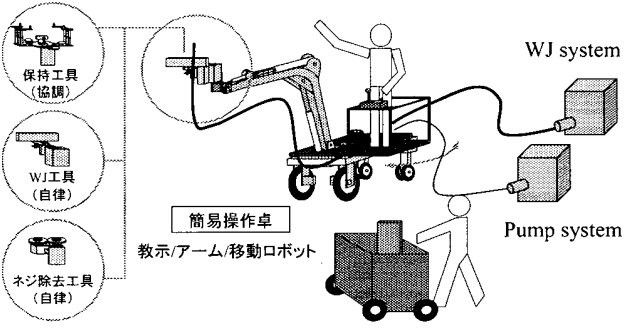

Fig. 2 Image of mobile working robot

移動作業ロボットは, 移動ロボット部, マニピュレータ部, 手先工具部から構成される。ここで，移動ロボット部で大ま かな位置決めを, マニピュレータ部で軽鉄付近に, 手先工具 で軽鉄位置を追従する階層追従方式とした，階層に於る形態 としダイナミックレンジを移動ロボット $5000[\mathrm{~mm}]$, マニピュ レータ $1000[\mathrm{~mm}]$, 手先工具 $50[\mathrm{~mm}]$ とし, その $1 \%$ 精度の目 安とした。（図 3)

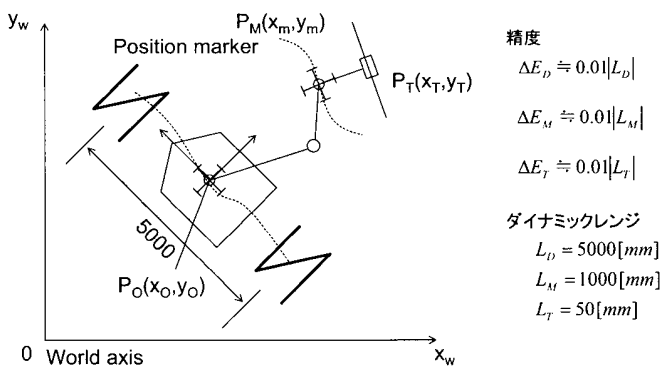

Fig. 3 Accuracy and dynamic range 


\section{3. 移動作業ロボットのアーキテクチャー}

3.1 システム統合アーキテクチャー

移動作業ロボットは前述のように分散アーキテクチャーを 用いている，そのため，各機器でモジュール化を行う。図 4 に機能アーキテクチャーを示す.

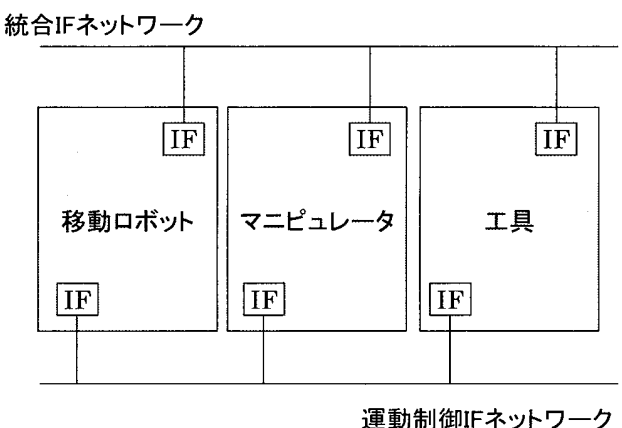

Fig.4 Function architecture

3.2 機能アーキテクチャーMフトウェアアーキテクチャー ロボットを構成する各機器（モジュール）の機能アーキテ クチャーとソフトウェアアーキテクチャーは同様に設計する センシング系列 (以後, 列と称する) では，センサの距離情報 より，センシング結果 Sensible(高い確率で物体あり)，№ Sensible (高い確率で物体無し)，GRAY (その他)を判定し，信 頼性列へ出力する．信頼性列では例外処理チェックを行い制 御入力 No Action(そのまま), Action(回避または停止), Caution (減速)， EMERGENCY (停止)を制御列へ出力する. 制御 列では制御入力を受けて距離に適合した制御を行う。図 5 に 移動ロボット, 図 6 にマニピュレータ, 図 7 に手先工具の機 能アーキテクチャー(ソフトウェアアーキテクチャー)を示す.

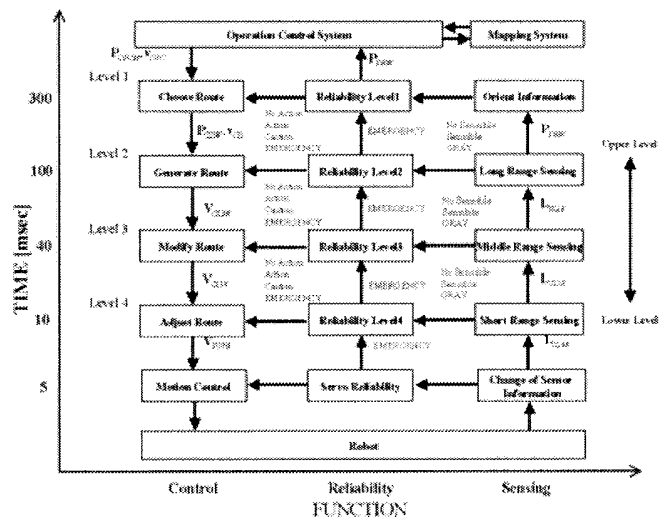

Fig.5 Function/software architecture of the mobile robot

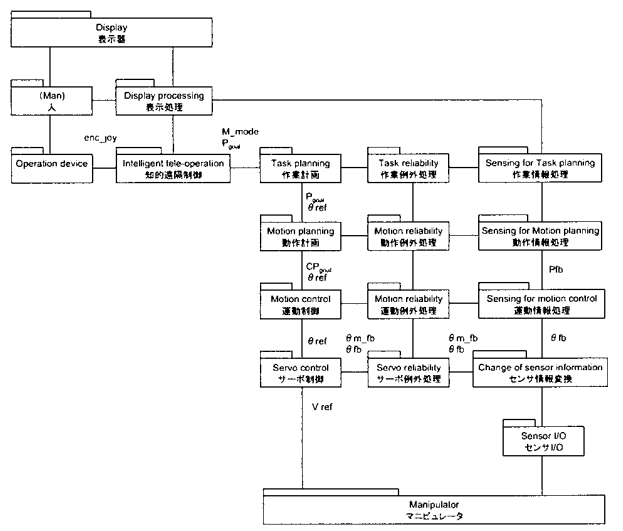

Fig.6 Function/software architecture of the manipulator

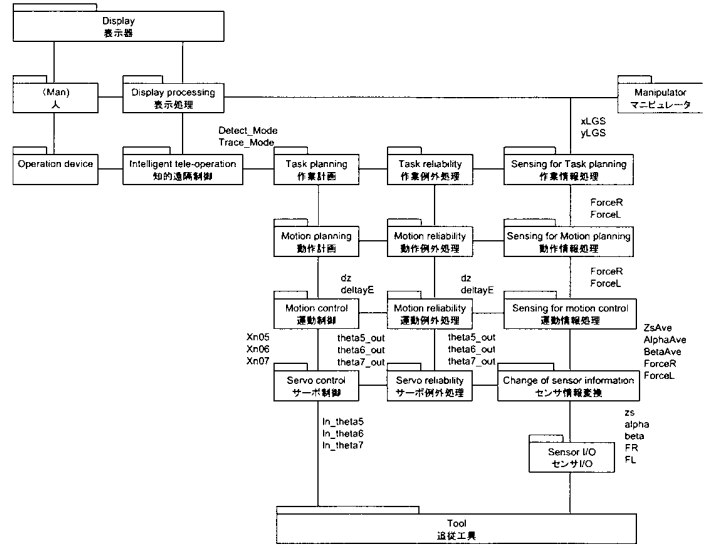

Fig.7 Function/software architecture of the tool

3.3 ネットワークアーキテクチャー

ネットワークアーキテクチャーはICN システムを使用した もので, 各機器の制御用 PC がイーサネットにより接続されて おり，PC と各機器間は CAN（Controller Area Network）に より接続され，これもネットワーク化されている. 図 8 に移 動ボットのネットワークアーキテクチャーとして ICN システ 厶構成を示す[4].今回の開発では ICN の代わりに PC を用い たが，考え方はICN システムと同様である。

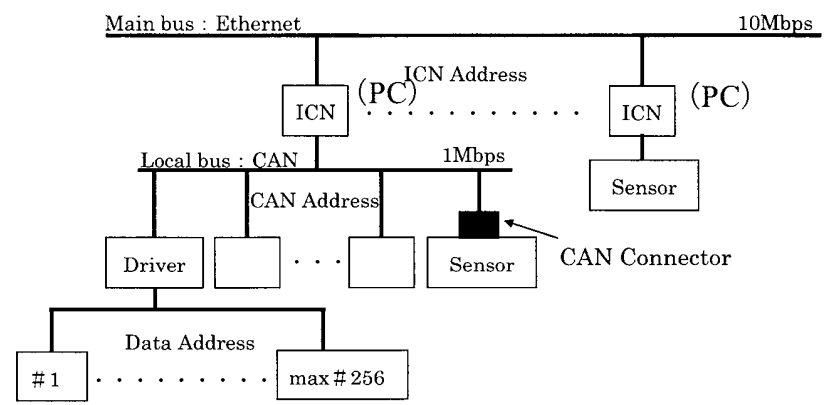

Fig. 8 Network architecture of the ICN

\section{1 移動ロボットの機械構成}

移動ロボットの機構構成図を図 9 に示す.移動機構は独立 2 輪操舵機構(2WD2WS)を採用し，4 つのモー夕を使用するこ とで，全方向全方位移動を可能とした.

\section{2 マニピュレータの機械構成}

マニピュレータの機構構成を図 10 に示す，マニピュレータ は旋回軸・ブーム・アーム・リストの 4 軸からなり，旋回軸 をモータ，ブーム・アーム・リストはシリンダで駆動する. 3 本のシリンダは水圧サーボ弁に配管され，水圧ユニットから の水圧を用いて関節角度の制御を行う。

\section{3 手先工具の機械構成}

手先工具の機構構成図を図 11 に示す. 手先工具は天井面追 従のための上下移動軸，軽鉄追従のための旋回軸 2 つから構 成される。 

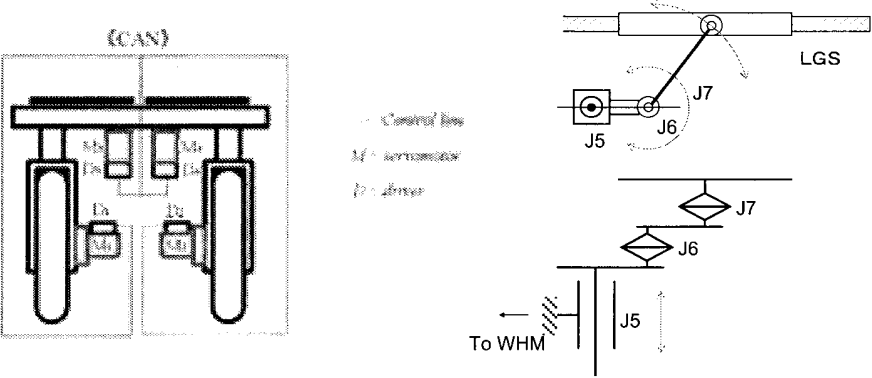

Fig. 9 Composition of mobile robot

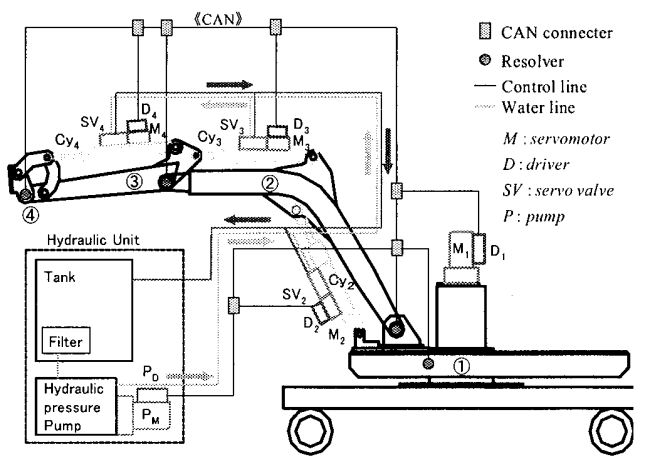

Fig. 10Composition of manipulator

\section{5. 機能評価実験}

\section{1 モックアップ実験}

解体対象となるビルの一部を再現した模擬試験場（モック アップ）を用意し，機能評価実験を行った。モックアップで は，以下の項目が再現されている。

- 天井の構造 : 軽鉄, 石膏ボード, 化粧版

・軽鉄の配置間隔 : 約 $0.3[\mathrm{~m}]$

これより, 評価可能な項目は

・軽鉄のリユース

- 工期の短縮

の 2 つが満たされているかの考察を行った.

開発した移動作業ロボットの概観を図 12 に示し，図 13 に モックアップの構成を示す.

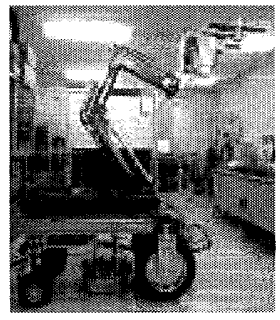

Fig. 12 Mobile working robot
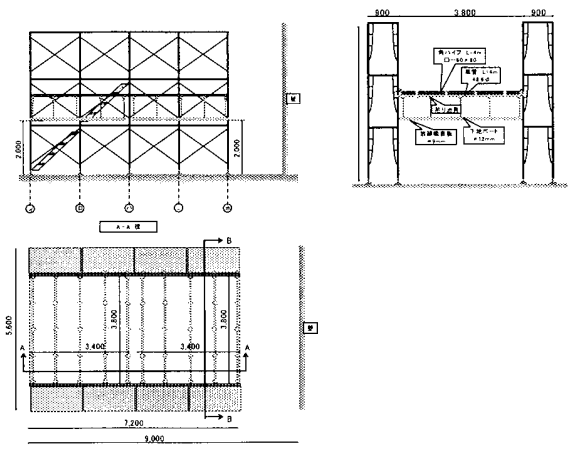

Fig. 13 Mock-up image

\section{2 実験結果}

モックアップで行った実験の様子を図 14 に，天井引き剥が し状況を図 15 に示し，天井ボード引き剥がし後の天井を図 16 に示す.

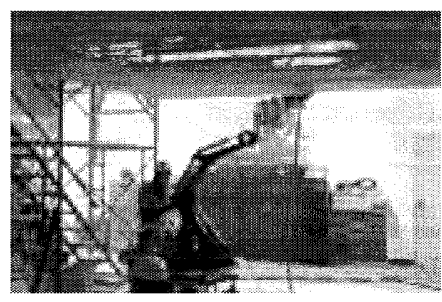

Fig. 14 Dismantlement work 1

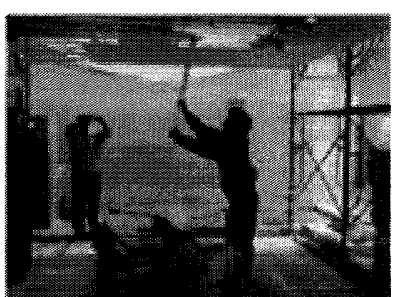

Fig. 15Dismantlement work 2

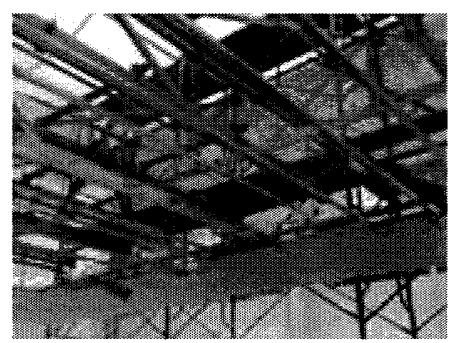

Fig. 16 Ceiling after it works

\section{3 切断評価}

図 16 に示すように解体作業は軽鉄を損傷することなく行わ れた。これにより，軽鉄のリユースが可能となる切断手法を 開発できたことが検証された.

\section{4 作業時間評価}

実験での総切断時間は 8.8[m²]に対し $134.4[\mathrm{sec}]$ を要した. これを $1000\left[\mathrm{~m}^{2}\right]$ での作業時間に換算すると 5.21 [hour] となる. よって，目標作業時閒は， 8 時間であるので，天井ボードの切 断が余裕を持って行えることが検証された。

\section{6. 結論}

（1）解体作業を可能とする移動作業ロボットシステム設計法 の開発を行った。

（2）移動作業ロボットに分散アーキテクチャーを採用し，そ の有用性を検証した。

（3）モックアップ実験において天井解体が可能であることを 示した.

\section{7. 参考文献}

[1] 前田純一郎，資材情報化による建築内装材の解体システム，第 8 回計測自動制御学会システムインテグレーション部門講演会予 稿集 (CDR), 1L2-1，2007.

[2] 大道武生，新井建生，神徳徹雄，谷川民生，前田純一朗; 廃材分 別を考慮した環境保全型解体作業口ボットの研究開発, 第 17 回 建設施工ロボットシンポジューム予稿集，pp33-38，2008.3.13

[3] 脇田昌明, 名和徹夫, 浅田輝彦, 大道武生 ; ウォータジェットに よる天井ボード高速解体手法の開発，ROBOMEC2008 予稿集 (CDR)，2P1-B10, 2008

[4] 小阪正朋, 福森聡哲, 㝨田進平, 鬼頭孝嘉, 大道武生 ; CAN コ ネクタの応用性に関する研究 第 7 回計測自動制御学会システ ムインテグレーション部門講演会予稿集（CDR）3B1-6，2006 